\title{
Identification of Mycobacterium bovis antigens by analysis of bovine T-cell responses after infection with a virulent strain
}
A. Alito ${ }^{1}$, J. McNair ${ }^{2}$,
R.M. Girvin' ${ }^{2}$,
M. Zumarraga ${ }^{1}$,
F. Bigi ${ }^{1}$, J.M. Pollock ${ }^{2}$
and A. Cataldi ${ }^{1}$

\author{
${ }^{1}$ Institute of Biotechnology, CICVyA-INTA, Castelar, Argentina \\ ${ }^{2}$ Veterinary Sciences Division, Department of Agriculture and Rural Development, \\ Stormont, Belfast, Northern Ireland, UK
}

\section{Correspondence \\ A. Cataldi \\ Institute of Biotechnology \\ CICVyA-INTA \\ Castelar \\ 1712 Argentina \\ Fax: +54-11-4481-2975 \\ E-mail: acataldi@cnia.inta.gov.ar \\ Research supported in part by the \\ Centro Argentino Brasileño de \\ Biotecnología (CABBIO). F. Bigi and \\ A. Cataldi are fellows of the \\ National Research Council of \\ Argentina (CONICET).}

Received February 4, 2003

Accepted July 22, 2003

\begin{abstract}
Purification and characterization of individual antigenic proteins are essential for the understanding of the pathogenic mechanisms of mycobacteria and the immune response against them. In the present study, we used anion-exchange chromatography to fractionate cell extracts and culture supernatant proteins from Mycobacterium bovis to identify T-cell-stimulating antigens. These fractions were incubated with peripheral blood mononuclear cells (PBMC) from $M$. bovis-infected cattle in lymphoproliferation assays. This procedure does not denature proteins and permits the testing of mixtures of potential antigens that could be later identified. We characterized protein fractions with high stimulation indices from both culture supernatants and cell extracts. Proteins were identified by two-dimensional gel electrophoresis followed by N-terminal sequencing or MALDI-TOF. Culture supernatant fractions containing low molecular weight proteins such as ESAT6 and CFP10 and other proteins (85B, MPB70), and the novel antigens TPX and TRB-B were associated with a high stimulation index. These results reinforce the concept that some low molecular weight proteins such as ESAT6 and CFP10 play an important role in immune responses. Also, Rv3747 and L7/L12 were identified in high stimulation index cell extract fractions. These data show that protein fractions with high lymphoproliferative activity for bovine PBMC can be characterized and antigens which have been already described and new protein antigens can also be identified in these fractions.
\end{abstract}

\section{Introduction}

Bovine tuberculosis caused by Mycobacterium bovis is an animal health problem throughout the world and also constitutes a major threat to public health. On the American continent there are 420 million heads of
Key words

- Bovine tuberculosis

- Antigens

- Mycobacterium bovis

- Cellular immunity cattle, half of which are in countries in which the incidence of bovine tuberculosis is higher than $1 \%$. There are 50,600,000 Argentine heads of cattle, with $5 \%$ of the animals and $35 \%$ of the farms being infected with bovine tuberculosis (1). Eradication of this zoonotic disease remains an important goal in several 
countries. The strategy of test and slaughter has been used widely in an attempt to control dissemination of the disease and is based on the tuberculin skin test as a means for bovine tuberculosis diagnosis. However, implementation of tuberculin tests is cumbersome, requiring a second visit by the veterinarian three days after the tuberculin injection. Some bovine tuberculosis eradication programs have incorporated variants of this test but suboptimal sensitivity and specificity have frequently been reported $(2,3)$. This is considered to be due, in part, to the nature of the poorly characterized antigens used, which are mycobacterial extracts containing components that are not species specific (3). Therefore, more sensitive and specific tests, probably incorporating better defined antigens, are required for efficient detection of this disease.

It is well established that T-cell recognition of mycobacterial antigens is the major immune response to tuberculosis (4-6). Therefore, an effective diagnostic test can be developed if well-characterized T-cell-reactive antigens are identified. This fact has led several research groups to the identification of antigens recognized by immune cells.

One of the main objectives of the present study was to identify the dominant $M$. bovis antigens that are recognized by the bovine cellular immune system. Unlike previous studies, which have focused on secreted antigens, the present study investigated cellular as well as secreted proteins. In addition, we used culture supernatants harvested at various times of the culture to determine if different antigens were released along the growth curve. This was achieved by separating $M$. bovis culture supernatant and whole cell proteins and testing the antigenicity of the resulting fractions by a lymphoproliferation assay (LPA) using peripheral blood mononuclear cells (PBMC) from experimentally infected cattle. This approach allows a fast step of preselection of immunodominant fractions from which it is easy to identify antigenic proteins.

\section{Material and Methods}

\section{Bacterial strains, media and preparation of culture supernatant and cell extracts}

The $M$. bovis AN5 standard strain was used throughout the study. Cultures were prepared in Middlebrook 7H9 liquid medium containing $0.4 \%$ pyruvic acid and glucose. Mycobacterial cultures were incubated at $37^{\circ} \mathrm{C}$ and harvested at 24, 38 and 73 days. The supernatants were separated from the cell extract by centrifugation and then filtered through a 0.22- $\mu \mathrm{m}$ Millipore membrane (Bedford, MA, USA) to remove remaining mycobacteria. The proteins were then precipitated with ammonium sulfate $(50 \%)$ for $18 \mathrm{~h}$ at $4^{\circ} \mathrm{C}$. Following centrifugation at 10,000 rpm for $1 \mathrm{~h}$ the precipitate was dissolved in a minimal volume of phosphate-buffered saline (PBS) and then dialyzed against PBS for $18 \mathrm{~h}$ at $4^{\circ} \mathrm{C}$. After removing the culture supernatant the cell mass was washed and resuspended in PBS. Mycobacteria were killed by heat (20 min at $80^{\circ} \mathrm{C}$ ) and sonicated on ice five times for 1 min with rest intervals of $2 \mathrm{~min}$. Cell extracts were obtained from a 38-day culture.

The protein content of the supernatants and cell extracts was measured by the bicinchoninic acid method (Pierce, Rockford, IL, USA).

\section{Animals}

Four Friesian cattle were selected from a herd known to be free from bovine tuberculosis during the previous five years. These animals were confirmed as bovine tuberculosis negative by testing in vitro $\mathrm{T}$-cell responses to mycobacterial antigens. The animals were placed in strict isolation under ventilation with negative pressure. They were infected by intranasal instillation with $10^{6}$ CFU of a wild-type strain of $M$. bovis using previously described methods (6). Two animals of the same age and origin were used as uninfected controls. 


\section{Protein purification}

Proteins from cell-free supernatants and cell extracts were separated using FPLC anion-exchange column chromatography (Pharmacia, Uppsala, Sweden). Protein, 0.5 to 5.0 $\mathrm{mg}$, was loaded onto a Mono-Q column (Pharmacia) equilibrated with $20 \mathrm{mM}$ Tris buffer, $\mathrm{pH}$ 8.0. Proteins bound to the column were eluted using a linear $\mathrm{NaCl}$ gradient $(0-0.4125$ $\mathrm{M})$ while the proteins that bound very strongly were removed with $1 \mathrm{M} \mathrm{NaCl}$. The flow rate was $0.5 \mathrm{ml}$ per min and 84 fractions of $0.5 \mathrm{ml}$ each were collected. Protein elution from the column was monitored by absorbance at 280 $\mathrm{nm}$. All fractions were analyzed by SDSPAGE (7) and proteins were visualized using a silver stain procedure (8). To simplify the screening, protein fractions from the major peaks of the chromatogram that had similar protein profiles (as determined by SDS-PAGE) were pooled. Pools were dialyzed against PBS, filter-sterilized and protein concentration was measured for use in LPA using PBMC from the experimentally infected cattle.

\section{Lymphoproliferation assay}

Blood was collected from four experimentally infected animals 11 months after M. bovis inoculation. PBMC were separated by centrifugation over Ficoll-Histopaque (Pharmacia) and viability of the PBMC preparation was determined by Trypan blue exclusion. Microcultures were prepared with $10^{6}$ cells/ml in RPMI 1640, supplemented with $10 \%$ fetal bovine serum, $2 \mathrm{mM}$ L-glutamine and $25 \mu \mathrm{g} / \mathrm{ml}$ gentamicin sulfate. The antigenic fractions obtained by FPLC were added to $200-\mu 1$ cultures (in triplicate) at a standard protein concentration of $4 \mu \mathrm{g} / \mathrm{ml}$. Total culture supernatant or cell extract was also included as positive control, also at $4 \mu \mathrm{g} / \mathrm{ml}$ protein. Purified protein derivative (PPD) prepared from M. bovis was used as a positive antigen control and concanavalin $\mathrm{A}$
(4 $\mu \mathrm{g} / \mathrm{ml})$ was used to measure the viability of separated PBMC. PBMC cultures were incubated at $37^{\circ} \mathrm{C}$ and in the presence of $5 \%$ $\mathrm{CO}_{2}$. After 4 days, the cultures were pulsed with tritiated thymidine $(1 \mu \mathrm{Ci}$ per well $)$ and lymphoproliferation was terminated $18 \mathrm{~h}$ later by harvesting the cells onto a filter mat using a Skatron harvester (Skatron, Lier, Norway). Radioactivity was measured using a Betaplate counter (Pharmacia) and the results are reported as stimulation indices (SI) calculated from the ratio of cpm incorporated with antigen to $\mathrm{cpm}$ incorporated without antigen (PBS was added in the place of antigen).

\section{Identification of individual proteins in stimulatory fractions}

Two-dimensional electrophoresis. The standard method of O'Farrell (9) was used. Briefly, 30 to $50 \mu \mathrm{g}$ proteins were dialyzed against $40 \mathrm{mM}$ Tris- $\mathrm{HCl}, \mathrm{pH} 9.5$, concentrated using a Millipore cartridge with a cutoff of $3 \mathrm{kDa}$, and solubilized with a buffer consisting of $9.5 \mathrm{M}$ urea, 2\% NP40, 5\% mercaptoethanol and a mix of ampholytes (0.8\%; BioLyte, BioRad Laboratories, Richmond, CA, USA), $\mathrm{pH}$ ranges 3-10:5-7 in a 1:4 relationship. Twenty microliters of this mix was loaded onto a first dimension-isoelectrofocusing gel (9.16 M urea, 2\% NP40, $4.25 \%$ acrylamide-bisacrylamide mix (30:5.4\%), $2 \%$ of the ampholyte mix mentioned above, $0.02 \%$ TEMED, and $0.2 \%$ ammonium persulfate). Electrophoresis was performed in $20 \mathrm{mM} \mathrm{NaOH}$ (cathode buffer) and $10 \mathrm{mM} \mathrm{PO} \mathrm{PH}_{3}$ (anode buffer) at room temperature at $200 \mathrm{~V}$ for $90 \mathrm{~min}$, followed by $400 \mathrm{~V}$ for $12 \mathrm{~h}$ and $950 \mathrm{~V}$ for $2 \mathrm{~h}$. The second dimension run was performed on 12.5 or $15 \%$ SDS-PAGE gel. The proteins were either silver stained or transferred to a PVDF membrane and subsequently stained with Coomassie blue.

$N$-terminal sequencing of proteins. The $\mathrm{N}$-terminal sequencing of selected proteins immobilized on PVDF membranes was 
Figure 1. SDS-PAGE of culture supernatants harvested at 24 , 38 and 73 days of culture and cell extract (E). Proteins were stained with Coomassie blue and molecular weight markers (MWM) were applied to the left lane. Numbers on the left indicate the molecular mass in $\mathrm{kDa}$. performed by Edman degradation on the first six amino acids (Midwest Analytical, Inc., St. Louis, MO, USA). To identify the proteins the sequence was compared against a database of $M$. tuberculosis proteins (www.sanger.ebi.ac.uk/Projects/ M_tuberculosis).

MALDI-TOF. Matrix-assisted laser desorption/ionization-time-of-flight (MALDITOF) mass spectrometry was performed using a Reflex III MALDI-TOF (Brukner Daltonik GmbH, Bremen, Germany) spectrometer on samples prepared as follows. Two-dimensional gels were stained with silver and the protein spots were sliced into small pieces with a stainless-steel scalpel or a vortex mixer and placed in siliconized microcentrifuge tubes. Gel pieces were destained with a ferricyanide-thiosulfate solution and washed in 50\% acetonitrile containing $25 \mathrm{mM}$ ammonium bicarbonate, $\mathrm{pH}$ 8.0 (three times, $15 \mathrm{~min}$ each, $24^{\circ} \mathrm{C}$ ). Gel slices were dehydrated in $100 \%$ acetonitrile for $10 \mathrm{~min}$, the acetonitrile was removed, and the gel slices were dried under vacuum for $30 \mathrm{~min}$. Samples were rehydrated with sequencing-grade trypsin solution $(5 \mu \mathrm{g} / \mathrm{ml}$ in $25 \mathrm{mM}$ ammonium bicarbonate, $\mathrm{pH} 8.0$ ) and incubated overnight at $32^{\circ} \mathrm{C}$. Peptides were extracted with $50 \%$ acetonitrile- $2 \%$ tri-

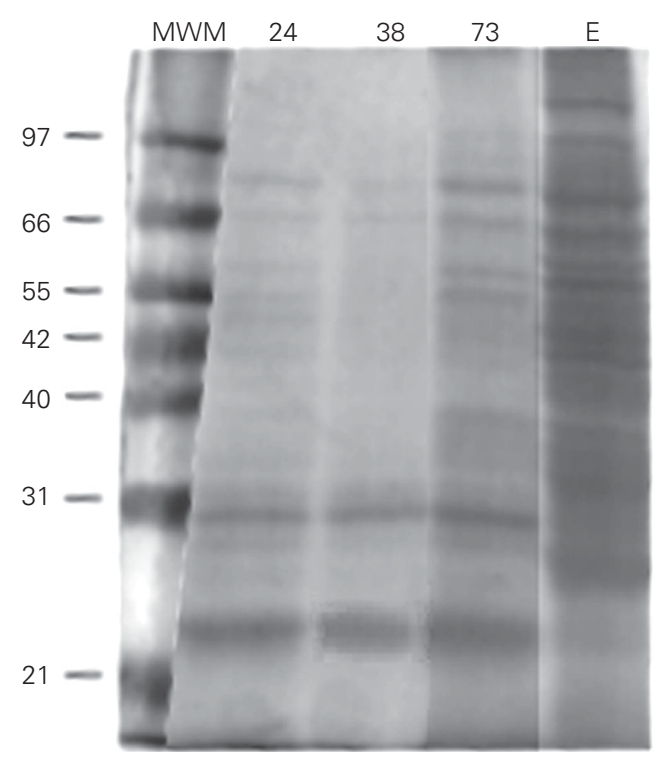

fluoroacetic acid in distilled water and concentrated with a Speed-Vac. Samples were mixed with the matrix $\alpha$-cyano-4-hydroxycinnamic acid and analyzed by MALDI-TOF. Mass spectrometry profiles were searched against the National Center for Biotechnology Information database.

SDS-PAGE and Western blot. Antigenic fractions were resuspended in loading buffer (2\% SDS, 0.125 M Tris-HCl, pH 6.8, $1 \% 2$ mercaptoethanol, $0.02 \%$ bromophenol blue, and $10 \%$ glycerol), heated for $5 \mathrm{~min}$ in boiling water, and loaded onto $12.5 \%$ polyacrylamide gels by the method of Laemmli (7). Molecular mass standards (low and high range, BioRad) were run on each gel. Proteins were electrotransferred onto a nitrocellulose sheet (Sleicher and Schuell, Dassel, Germany) by the semidry transfer method (10). The efficiency of transfer was visualized by transient staining with Ponceau red. Membranes were blocked with 5\% nonfat milk in TBS (50 mM Tris- $\mathrm{HCl}, \mathrm{pH} 8$, and $150 \mathrm{mM} \mathrm{NaCl}$ ), incubated with the first antibody overnight at $4^{\circ} \mathrm{C}$ and, after three washes with TBS, incubated with alkaline phosphatase-conjugated anti-rabbit or anti-mouse IgG (Sigma, St. Louis, MO, USA) at 1/1000 dilution for $2 \mathrm{~h}$ at $37^{\circ} \mathrm{C}$. After three washes with TBS and one wash with alkaline phosphatase buffer (100 mM Tris- $\mathrm{HCl}, \mathrm{pH}$ 9.5, $100 \mathrm{mM} \mathrm{NaCl}$, and $5 \mathrm{mM} \mathrm{MgCl}_{2}$ ), a color reaction was developed by adding 5-bromo4-chloro-3-indolylphosphate (BCIP) and toluidine nitroblue tetrazolium (NBT) as substrates. After $20 \mathrm{~min}$ the color reaction was stopped by adding water.

Antisera and antibodies. Anti-ESAT6 monoclonal antibody was kindly provided by Ida Rosenkrands and Peter Andersen (Statens Serum Institute, Copenhagen, Denmark). Anti-MPB70 monoclonal antibody (4C3/17) was purchased from CSL (Victoria, Australia). Polyclonal antisera recognizing 85B were kindly provided by T. Fifis (Animal Health Research Laboratories, Victoria, Australia). 


\section{Results}

Fractionation of culture supernatants and cell extracts by anion-exchange chromatography

Culture supernatants, harvested at three different culture times (24, 38 and 73 days), and cell extracts were fractionated by FPLC anion-exchange chromatography with a linear gradient of $0-0.42 \mathrm{M} \mathrm{NaCl}$. As indicated in Figure 1, nonfractionated supernatant and extracts were complex mixtures of several individual proteins. In the culture supernatant fractions, proteins of $<10,20,22,24,31,32,40$, 43, 45, 50, 65 and $75 \mathrm{kDa}$ were observed. In cell extracts, heavily stained bands were seen at 10, 14, 16, 20, 22, 24, 31, 40, 66 and $71 \mathrm{kDa}$.

When culture supernatants and cell extract preparations were separated by anionexchange chromatography, four (24-day culture supernatant) to three (73-day culture supernatant and cell extract) major peaks were observed in the gradient zone. A chromatogram from a 73-day culture supernatant is shown in Figure 2 as an example. Protein profiles for each fraction were determined by SDS-PAGE. Figure 3 shows the fractions from a 38-day culture supernatant.

Fractions having a similar protein profile, from each chromatogram peak, were pooled and dialyzed and their concentration was measured and used for LPA using PBMC from four animals experimentally infected with $M$. bovis. Two uninoculated animals of the same age, sex and source were used as uninfected controls.

\section{T-cell responses to chromatographic fractions}

The FPLC profile of the 24-day culture supernatant contained five peaks. Pools from these regions were prepared, representing fractions 11-17, 20-24, 25-28, 32-36, and 81-84 (Table 1). Some of these fractions showed an SI equal to or higher than that of PPD. The mean reactivity of pools was $25-$ $28>20-24=32-36>81-84>11-17$, except for animal 4 where pool 81-84 was the more reactive. SDS-PAGE analysis of the most stimulatory pool (25-28) showed proteins of $<10 \mathrm{kDa}$ and a less intense band of $20 \mathrm{kDa}$. Fraction 20-24 had intense bands of 20, 25, 32 and $41 \mathrm{kDa}$. The 32-36 pool had a $<10-$ kDa protein, while the 81-84 pool had a 20$\mathrm{kDa}$ protein and the lowest stimulatory pool (11-17) showed bands of 20, 31 and $32 \mathrm{kDa}$ and additional weaker bands.

Four peaks were observed during the sepa-

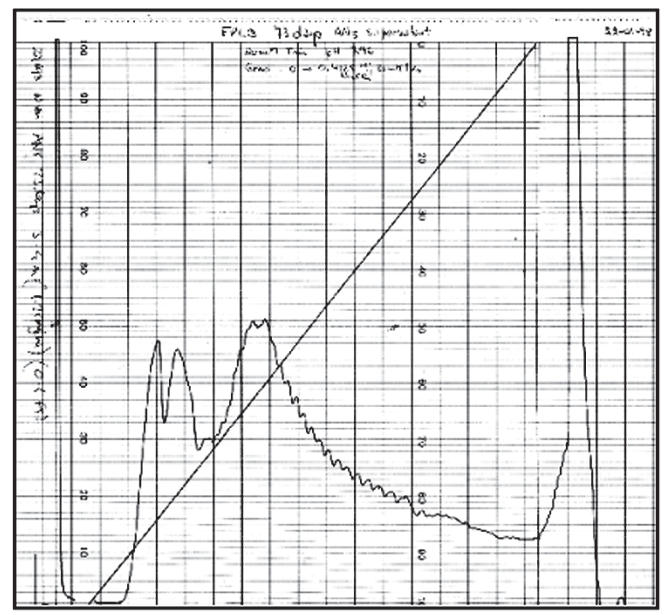

Figure 2. A representative anion-exchange chromatogram of a 73-day culture supernatant. Ordinate: absorbance at 280 $\mathrm{nm}$. Abscissa: fraction numbers.

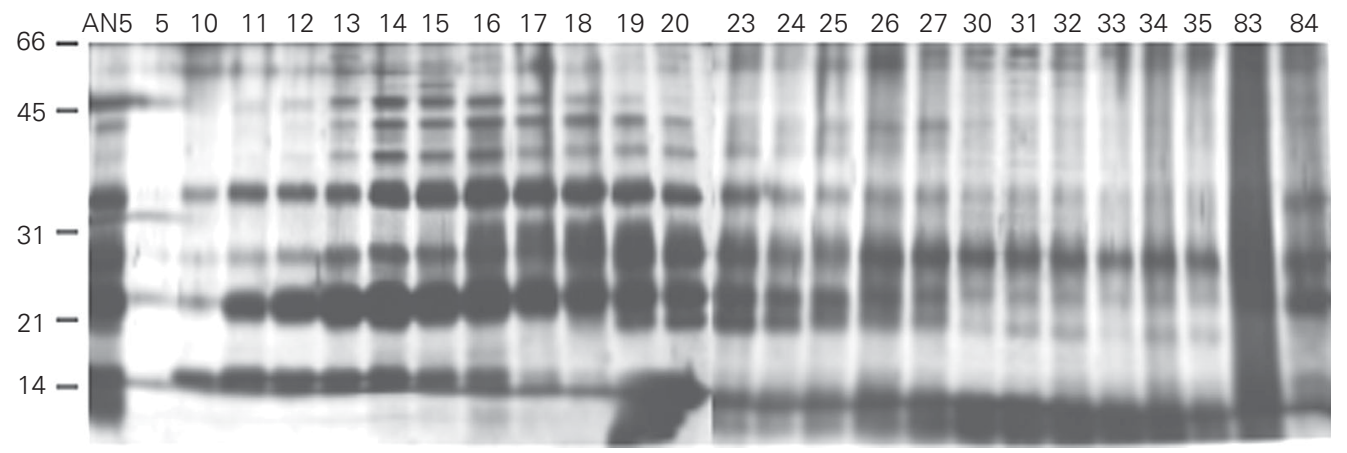

Figure 3. SDS-PAGE analysis of the anion-exchange chromatography elution profile of 38-day AN5 culture supernatants. The fraction number is indicated above each lane. AN5 = culture supernatants before chromatography. Note the relatively large amounts of low MW proteins in fractions 30 to 35 . Numbers on the left indicate the molecular mass in $\mathrm{kDa}$. 
ration of the 38-day culture supernatant. Pools were prepared from fractions 17-18, 25-26, $30-34$, and 83 (Table 1). The reactivity order of the pools was 30-34>83>25-26>17-18,

Table 1. Stimulation indices obtained in a lymphoproliferation assay.

\begin{tabular}{|c|c|c|c|c|c|c|}
\hline \multirow[t]{3}{*}{ Antigen } & \multicolumn{6}{|c|}{ Stimulation index } \\
\hline & \multicolumn{4}{|c|}{ Infected animals } & \multicolumn{2}{|c|}{ Noninfected animals } \\
\hline & 1 & 2 & 3 & 4 & 88 & 99 \\
\hline \multicolumn{7}{|c|}{ Culture supernatant - 24 days } \\
\hline PBS & $1(158)$ & $1(63)$ & $1(67)$ & $1(103)$ & $1(234)$ & $1(170)$ \\
\hline Con A & 13 & 49 & 97 & 200 & 352 & 277 \\
\hline PPD B & 13 & 23 & 86 & 217 & 1.71 & 2.02 \\
\hline Pool 11-17 & 5 & 5 & 21 & 17 & 1.06 & 1.70 \\
\hline Pool 20-24 & 25 & 57 & 27 & 294 & 1.37 & 2.00 \\
\hline Pool 25-28 & 28 & 68 & 24 & 303 & 1.06 & 1.96 \\
\hline Pool 32-36 & 26 & 56 & 26 & 177 & 1.77 & 1.52 \\
\hline Pool 81-84 & 9 & 27 & 9 & 345 & 1.26 & 2.29 \\
\hline \multicolumn{7}{|c|}{ Culture supernatant - 38 days } \\
\hline PBS & $1(433)$ & $1(330)$ & $1(477)$ & 1 (389) & $1(234)$ & $1(170)$ \\
\hline Con A & 126 & 234 & 148 & 119 & 352 & 277 \\
\hline PPD B & 109 & 55 & 71 & 64 & 1.71 & 2.02 \\
\hline $\mathrm{TP}$ & 123 & 50 & 49 & 48 & 1.70 & 1.74 \\
\hline Pool 17-18 & 32 & 12 & 12 & 89 & 1.10 & 1.04 \\
\hline Pool 25-26 & 80 & 45 & 21 & 73 & 0.70 & 1.24 \\
\hline Pool 30-34 & 64 & 91 & 14 & 136 & 1.07 & 1.32 \\
\hline Pool 83 & 118 & 67 & nd & 108 & 2.23 & 3.29 \\
\hline \multicolumn{7}{|c|}{ Culture supernatant - 73 days } \\
\hline PBS & $1(433)$ & $1(330)$ & $1(477)$ & 1 (389) & $1(234)$ & $1(170)$ \\
\hline Con A & 126 & 234 & 148 & 119 & 352 & 277 \\
\hline PPD B & 109 & 55 & 71 & 64 & 1.71 & 2.02 \\
\hline $\mathrm{TP}$ & 120 & 59 & 40 & 105 & 2.70 & 1.04 \\
\hline Pool 14-16 & 110 & 55 & 28 & 75 & 1.42 & 1.24 \\
\hline Pool 17-18 & 107 & 62 & 31 & 50 & 2.08 & 1.72 \\
\hline Pool 22-23 & 107 & 93 & 30 & 57 & 0.98 & 1.52 \\
\hline Pool 25-28 & 98 & 73 & 31 & 97 & 1.09 & 1.92 \\
\hline Pool 29-31 & 97 & 68 & 32 & 113 & 2.10 & 1.46 \\
\hline Pool 81 & 96 & 54 & 15 & 103 & 1.76 & 2.97 \\
\hline \multicolumn{7}{|l|}{ Cell extract } \\
\hline PBS & 1 (98) & $1(68)$ & $1(567)$ & $1(200)$ & nd & 1 (325) \\
\hline Con A & 542 & 980 & 540 & 607 & nd & 250 \\
\hline PPD B & 109 & 55 & 71 & 64 & nd & 2.30 \\
\hline Pool 6-14 & 113 & 25 & 34 & 16 & nd & 3.09 \\
\hline Pool 20-24 & 225 & 93 & 234 & 408 & nd & 2.40 \\
\hline Pool 25-29 & 623 & 178 & 76 & 52 & nd & 2.47 \\
\hline Pool 30-32 & 660 & 186 & 98 & 57 & nd & 3.25 \\
\hline Pool 33-40 & 606 & 161 & 102 & 46 & nd & 3.42 \\
\hline Pool 82-84 & 457 & 30 & 43 & 11 & nd & 1.26 \\
\hline
\end{tabular}

All assays used a protein concentration of $4 \mu \mathrm{g} / \mathrm{ml}$. Values given within parentheses in $\mathrm{cpm}$ are for PBS control. Con $\mathrm{A}=$ concanavalin $\mathrm{A}$; $\mathrm{nd}=$ not determined; PPD $\mathrm{B}=$ purified protein derivative $B ; T P=$ non-fractionated proteins . except for animal 1 where 83 was the more reactive pool. SDS-PAGE analysis (Figure 3 ) of the low stimulatory pool (17-18) showed prominent bands of 16,20 and $32 \mathrm{kDa}$, as well as additional bands of 24, 40, 43 and 45 $\mathrm{kDa}$. Pool 25-26 had proteins of 14, 16, 20, 24,31 , and $44 \mathrm{kDa}$ (doublet), and less intense low molecular weight proteins. The most stimulatory pool (30-34) showed an intense $<10-\mathrm{kDa}$ band (Figure 3) and a 24$\mathrm{kDa}$ protein, with minor bands of 43 and 45 $\mathrm{kDa}$ as well as other bands. Fraction 83 had proteins of 14 and $16 \mathrm{kDa}$ (Table 1).

The T-cell-proliferative response was similar for all six pools analyzed (14-16, 17 $18,22-23,25-28,29-31,81)$ from the 73-day culture supernatant (Table 1). SDS-PAGE analysis showed that all of them, except fraction 81, contained protein bands $<10$ $\mathrm{kDa}$, with little difference in the protein profile of all these pools. Major bands were seen at $<10,14.5,20,22,24,25,32,40,44$ and $46 \mathrm{kDa}$.

Using whole cell extract, six peaks were observed. Pools were prepared from fractions 6-14, 20-24, 25-29, 30-32, 33-40 and 82-84. Many fractions showed an SI equal to PPD or higher. The reactivity order was roughly 30-32 > 25-29 > 33-40 $>20-24>82$ $84>6-14$ for animals 1 and 2, and 20-24 > $30-32>33-40>25-29>82-84=6-14$ for animals 3 and 4. SDS-PAGE analysis of fraction 30-32 showed proteins of $<10,19$, 25,40 and $70 \mathrm{kDa}$. Fraction 20-24 contained proteins of $<10,12,14,19,25,30,40$ and 70 $\mathrm{kDa}$. Fraction 6-14 contained proteins of $<10,19,25,30,40,45,66$ and $70 \mathrm{kDa}$. Finally, fraction 82-84 showed several heavily stained and smeared bands.

When PBMC from healthy, noninfected animals were stimulated with pools of the fraction, very low SI were observed (Table 1 , animals 88 and 99).

To assess the functionality of the methodology (PBMC preparation and LPA) throughout the experiment, we analyzed the indices of concanavalin A stimulation for all 
four animals, which were found to be highly uniform. Variations in LPA from animal to animal and within individual animals throughout the experiments were determined by analyzing LPA results when PPD was used as antigen.

\section{Identification of proteins in antigenic fractions}

Six proteins were identified in fractions 25-28 from 24-day culture supernatants and in fractions 30-34 from 38-day culture supernatants. They were CFP10 (11 kDa), ESAT6 (9 kDa), TRB-B (36 kDa), 85B (32 kDa), TPX (17 kDa), and MPB70 (20 kDa) (Table 2). N-terminal sequences of $85 \mathrm{~B}$, MPB70 and TRB-B are compatible with signal sequences. Specific antisera were used to confirm the identification of MPB70 and $85 \mathrm{~B}$ by Western blot (data not shown). ESAT6 was identified only by Western blot (data not shown).

Several cell extract fractions from 38day cultures showed stimulatory properties. We concentrated on one of them (fraction 30-32) that showed high T-cell reactivity. Since the N-terminus seemed to be blocked in most proteins, we used MALDI-TOF for protein identification. Two proteins were identified: Rv3747 (13 kDa) and L7/L12 (13 kDa) (Table 2). Proteins corresponding to three other spots could not be identified.

\section{Discussion}

In this study we used a novel approach to detect T-cell-stimulating antigens from $M$. bovis, i.e., fractionation of antigens using anion-exchange chromotagraphy. Other investigators have used anion-exchange columns to purify antigens already identified in M. bovis (11). Compared to protein separation by SDS-PAGE, the advantage of the present methodology is that antigens are maintained in the native state. In addition, we screened antigens from cell extracts as well as culture supernatant proteins. Finally, we harvested culture supernatant proteins at various times instead of using a single sample to test whether the bacteria might secrete different proteins during the growth phases.

Since cellular responses are the major immune mechanism in tuberculosis, T-cell reactivity toward well-characterized mycobacterial antigens has been extensively studied $(5,12,13)$. However, the direct screening of antigens with immune cells is technically much more complicated compared to antigen-antibody interactions. Several approaches have been used previously to test soluble antigens prepared from a nitrocellulose membrane or "T-cell Western blot" (1417). Mustafa et al. (18) performed direct screening of an $M$. tuberculosis expression library with PBMC, and identified a protein reacting with $\mathrm{T}$ cells but not with antibodies.

Electroelution from SDS-PAGE gels was first used by Gulle et al. (19) to obtain soluble antigens. Using a similar technique, Andersen and Heron (20) identified M. tuberculosis antigens related to memory response. Gulle et al. (21) screened BCG cellular and secreted proteins for $\mathrm{T}$-cell stimulant fractions using PBMC from cattle immunized with either viable or gamma-irradiated BCG. In contrast, in the present study, a virulent strain was used to infect cattle and to prepare proteins.

We identified protein in fractions prepared from both culture supernatants and cell extracts which, when tested by LPA, showed high SI. The selected fraction con-

\begin{tabular}{lcccc} 
Table 2. Identification of Mycobacterium bovis in antigenic fractions. \\
\hline Antigen & $\begin{array}{l}\text { N-terminal } \\
\text { sequence }\end{array}$ & $\begin{array}{c}\text { Position } \\
\text { in ORF }\end{array}$ & $\begin{array}{c}\text { Identification } \\
\text { by MALDI-TOF }\end{array}$ & $\begin{array}{c}\text { Confirmation by } \\
\text { Western blot }\end{array}$ \\
\hline CFP10 & AEMKTD & 2 & - & - \\
85B & FSRPGL & 41 & - & + \\
MPB70 & GDLVGP & 31 & + & + \\
ESAT6 & - & - & + & + \\
TPX & AQITLR & 2 & - & - \\
TRB-B & TELTGA & 16 & - & - \\
L7/L12 & - & - & + & - \\
RV3747 & - & - & + & -
\end{tabular}


tained several protein bands, some of them shared with other fractions while others were not. This allowed us to deduce which bands confer reactivity to the fraction. In 24- and 38-day culture supernatants, fractions associated with a high SI contained low molecular weight proteins $(<10 \mathrm{kDa})$ together with other proteins ranging from 20 to $35 \mathrm{kDa}$. In an attempt to identify individual antigens in antigenic fractions using a combination of methods, we determined that these stimulant fractions consisted of 85B, TRB-B, MPB70, TPX, CFP10 and ESAT6. 85B (22), ESAT6 $(6,23)$ and MPB70 (24-26) are well known T-cell-stimulating antigens, while the antigenicity of CFP10 has only recently been demonstrated $(23,25,27)$. These results support the view that low molecular weight proteins such as ESAT6 (6) play an important role in bovine immune responses to $M$. bovis. TRB-B and TPX are novel candidate antigens. While there are no previous references concerning TRB-B, TPX has been already identified as a protein by Rosenkrands et al. (28) and Weldingh et al. (29), who named it CFP20. Only two proteins, Rv3747 and L7/L12, could be identified in cell extracts. Rv3747 is a small protein with unknown function and L7/L12 is a ribosomal protein previously described as a major component of PPD (30). To fulfill one of our objectives of identifying $M$. bovis immunodominant antigens, the proteins described here should be made by recombinant methods and the antigenicity evaluated in infected cattle. These studies are underway in our laboratories.

Differences in the immunodominance of certain fractions were less marked in protein fractions derived from culture supernatants obtained at later times. An explanation may be the appearance in the culture supernatant of multiple antigens (proteins, complex lipids) released from the cells due to cell lysis. These antigens may mask the antigenicity of secreted low molecular weight proteins. Another explanation based on a lower content of low molecular weight proteins in late culture supernatants is less probable because we did not observe a decrease of low molecular weight proteins in late culture supernatants in SDS-Tricine-PAGE gels (data not shown). Subsequent close examination of gels indicated that the low molecular weight fraction is composed of several proteins, as demonstrated by SDS-Tricine-PAGE gels (data not shown). Our results differ from those of Diaz et al. (31) who worked with $M$. bovis AN5 culture supernatant proteins separated by isoelectrofocusing and screened with PBMC from naturally infected animals. These investigators did not report low molecular weight proteins in stimulating fractions, a fact possibly explained by apparent differences in SDS-PAGE conditions.

Importantly, we observed a strong stimulation using cell extract proteins. Most researchers agree that the main protective antigens are secreted proteins. However, nonsecreted, cell extract proteins may also be useful antigens for diagnosis, as we have reported in another study (32). It was difficult to identify a single pool from whole cell extracts which was clearly dominant. Gulle et al. (21) also showed strong antigenic responses from lysed cell proteins. As reported in other studies $(6,11,21)$, the $\mathrm{T}$-cell response presented considerable individual variability.

With the methodology described here we identified protein fractions that stimulate lymphoproliferation of bovine PBMC. Although one of the most stimulatory pools was highly enriched with low molecular weight protein, there were other stimulatory fractions such as those derived from cell extracts which contained higher molecular weight proteins. These fractions contain a complex mixture of proteins and must be further separated to identify individual T-cell-reactive antigens. 


\section{References}

1. de Kantor IN \& Ritacco V (1994). Bovine tuberculosis in Latin America and the Caribbean: current status, control and eradication programs. Veterinary Microbiology, 40: 5-14.

2. Pritchard DG (1988). A century of bovine tuberculosis 1888-1988, conquest and controversy. Journal of Comparative Pathology, 99: 357-399.

3. Monaghan ML, Doherty ML, Collins JD, Kazda JF \& Quinn PJ (1994). The tuberculin test. Veterinary Microbiology, 40: 111-124.

4. Orme IM \& Collins FM (1983). Protection against Mycobacterium tuberculosis infection by adoptive immunotherapy. Requirement for T-cell deficient recipients. Journal of Experimental Medicine, 158: 74-83.

5. Kaufmann SHE (1990). Immunity to mycobacteria. Research in Microbiology, 141: 765-768.

6. Pollock JM \& Andersen P (1997). Predominant recognition of the ESAT-6 protein in the first phase of interferon with Mycobacterium bovis in cattle. Infection and Immunity, 65: 2587-2592.

7. Laemmli UK (1970). Cleavage of structural proteins during the assembly of the head of bacteriophage T4. Nature, 227: 680-685.

8. Morrissey JH (1981). Silver stain for proteins in polyacrylamide gels: a modified procedure with enhanced uniform sensitivity. Analytical Biochemistry, 117: 307-310.

9. O'Farrell PH (1975). High resolution two-dimensional electrophoresis of proteins. Journal of Biological Chemistry, 250: 4007-4021.

10. Kyhse-Andersen J (1984). Electroblotting of multiple gels: a simple apparatus without buffer tank for rapid transfer of proteins from polyacrylamide to nitrocellulose. Journal of Biochemical and Biophysical Methods, 10: 203-209.

11. Fifis T, Rothel JS \& Wood PR (1994). Soluble Mycobacterium bovis protein antigens: studies on their purification and immunological evaluation. Veterinary Microbiology, 40: 65-81.

12. Young DB, Kaufmann SHE, Hermans PWM \& Thole JER (1992). Mycobacterial protein antigens: a compilation. Molecular Microbiology, 6: 133-145.

13. Andersen $P$ (1997). Host responses and antigens involved in protective immunity to Mycobacterium tuberculosis. Scandinavian Journal of Immunology, 45: 115-131.

14. Lamb JR \& Young DB (1987). A novel approach to the identification of T-cell epitopes in M. tuberculosis using human T-lymphocyte clones. Immunology, 60: 1-5.

15. Havlir DV, Wallis RS, Boom WH, Daniel TM, Chervenak K \& Ellner JJ (1991). Human immune response to Mycobacterium tuberculosis antigens. Infection and Immunity, 59: 665-670.

16. Carlucci S, Beschin A, Tuosto L, Ameglio F, Gandolfo GM, Cocito C, Fiorucci F, Saltini C \& Piccolella E (1993). Mycobacterial antigen complex A60-specific T-cell repertoire during the course of pulmonary tuberculosis. Infection and Immunity, 61: 439-447.

17. Torres $M$, Mendez-Sampeiro P, Jimenez-Zamudio L, Teran $L$, Camarena A, Quezada R, Ramos E \& Sada E (1994). Comparison of the immune response against Mycobacterium tuberculosis antigens between a group of patients with active pulmonary tuberculosis and healthy household contacts. Clinical and Experimental Immunology, 96: 75-78.

18. Mustafa AS, Oftung F, Deggerdal A, Gill HK, Young RA \& Godal T (1988). Gene isolation with human $T$ lymphocyte probes. Isolation of a gene that expresses an epitope recognized by T-cells specific for Mycobacterium bovis BCG and pathogenic mycobacteria. Jour- nal of Immunology, 141: 2729-2733.

19. Gulle H, Schoel B \& Kaufmann SHE (1990). Direct blotting with viable cells of protein mixtures separated by two dimensional electrophoresis. Journal of Immunological Methods, 133: 253-261.

20. Andersen P \& Heron I (1993). Simultaneous electroelution of whole SDS-polyacrylamide gels for the direct cellular analysis of complex protein mixtures. Journal of Immunological Methods, 161: 29-39.

21. Gulle H, Fray LM, Gormley EP, Murray A \& Moriarty KM (1995). Responses of bovine $T$ cells to fractionated lysate and culture filtrate proteins of Mycobacterium bovis BCG. Veterinary Immunology and Immunopathology, 48: 183-190.

22. Wiker HG \& Harboe M (1992). The antigen 85 complex: a major secretion product of Mycobacterium tuberculosis. Microbiological Reviews, 56: 648-661.

23. Vordermeier HM, Whelan A, Cockle PJ, Farrant L, Palmer N \& Hewinson RG (2001). Use of synthetic peptides derived from the antigens ESAT-6 and CFP-10 for differential diagnosis of bovine tuberculosis in cattle. Clinical and Diagnostic Laboratory Immunology, 8: 571-578.

24. Pollock JM, Girvin RM, Lightbody KA, Clements RA, Neill SD, Buddle $B M$ \& Andersen $P$ (2000). Assessment of defined antigens for the diagnosis of bovine tuberculosis in skin test-reactor cattle. Veterinary Record, 146: 659-665.

25. Rhodes SG, Gavier-Widen D, Buddle BM, Whelan AO, Singh M, Hewinson RG \& Vordermeier HM (2000). Antigen specificity in experimental bovine tuberculosis. Infection and Immunity, 68: 25732578.

26. Lightbody KA, Girvin RM, Mackie DP, Neill SD \& Pollock JM (1998). T-cell recognition of mycobacterial proteins MPB70 and MPB64 in cattle immunized with antigen and infected with Mycobacterium bovis. Scandinavian Journal of Immunology, 48: 44-51.

27. van Pinxteren LA, Ravn P, Agger EM, Pollock $J$ \& Andersen $P$ (2000). Diagnosis of tuberculosis based on the two specific antigens ESAT-6 and CFP10. Clinical and Diagnostic Laboratory Immunology, 7: 155-160.

28. Rosenkrands I, Weldingh K, Jacobsen S, Hansen CV, Florio W, Gianetri I \& Andersen P (2000). Mapping and identification of Mycobacterium tuberculosis proteins by two-dimensional gel electrophoresis, microsequencing and immunodetection. Electrophoresis, 21: 935-948.

29. Weldingh K, Rosenkrands I, Jacobsen S, Rasmussen PB, Elhay MJ \& Andersen $P$ (1998). Two-dimensional electrophoresis for analysis of Mycobacterium tuberculosis culture filtrate and purification and characterization of six novel proteins. Infection and Immunity, 66: 3492-3500.

30. Kitaura $H$, Kinomoto $M$ \& Yamada $T$ (1999). Ribosomal protein L7 included in tuberculin purified protein derivative (PPD) is a major heat-resistant protein inducing strong delayed-type hypersensitivity. Scandinavian Journal of Immunology, 50: 580-587.

31. Diaz F, Masso F, Paez A, Varela E, Suarez-Guemes F \& Montano LF (1999). Secretion of IFN-gamma by bovine peripheral blood mononuclear cells stimulated with Mycobacterium bovis protein fractions obtained by isoelectric-focusing. Veterinary Immunology and Immunopathology, 67: 203-212.

32. Cataldi AA, Romano MI \& Bigi F (1994). A Western blot study of $M$. bovis antigens recognized by cattle sera. Research in Microbiology, 145: 689-698. 